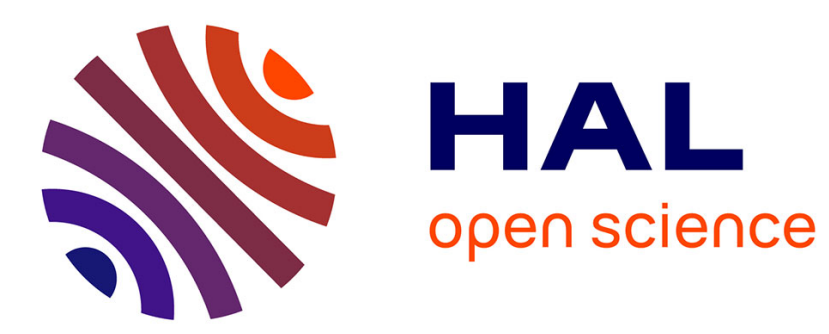

\title{
Carnosol purification. Scaling-up centrifugal partition chromatography separations
}

\author{
Elodie Bouju, Alain Berthod, Karine Faure
}

\section{To cite this version:}

Elodie Bouju, Alain Berthod, Karine Faure. Carnosol purification. Scaling-up centrifugal partition chromatography separations. Journal of Chromatography A, 2016, 1466, pp.59-66. 10.1016/j.chroma.2016.08.015 . hal-01515260

\section{HAL Id: hal-01515260 \\ https://hal.science/hal-01515260}

Submitted on 2 Sep 2020

HAL is a multi-disciplinary open access archive for the deposit and dissemination of scientific research documents, whether they are published or not. The documents may come from teaching and research institutions in France or abroad, or from public or private research centers.
L'archive ouverte pluridisciplinaire HAL, est destinée au dépôt et à la diffusion de documents scientifiques de niveau recherche, publiés ou non, émanant des établissements d'enseignement et de recherche français ou étrangers, des laboratoires publics ou privés. 


\title{
Carnosol purification. Scaling-up Centrifugal Partition Chromatography separations
}

\author{
Elodie Bouju $^{1,2}$, Alain Berthod ${ }^{1}$, Karine Faure ${ }^{1}$ \\ ${ }^{1}$ Université de Lyon, Institut des Sciences Analytiques, CNRS - 5, rue de la Doua, \\ 69100 Villeurbanne, France \\ ${ }^{2}$ Kromaton Sarl, groupe Rousselet-Robatel, 42 Avenue Rhin et Danube, 07100 Annonay, France
}

\begin{abstract}
This paper illustrates the use of a recently proposed protocol allowing predicting the scale-up on hydrostatic columns of countercurrent chromatography (centrifugal partition chromatographs or CPC). A commercial extract of rosemary (Rosmarinus officinalis L.) was used as the starting material containing $0.48 \%$ of carnosol, an active pharmaceutical ingredient with great potential. After a rapid method development on a small-scale 35-mL CPC instrument that allowed for the determination of the solvent system and maximum sample concentration and volume, the purification was transferred on two larger instruments using the "free space between peaks" method. The method takes into account the technical limitations of the larger instruments, such as pressure and/or maximum centrifugal field, and allows, by simply running an analytical-sized injection on the large scale rotor, to give an accurate prediction of the maximum sample load and best throughput. The $0.27 \mathrm{~g}$ of rosemary extract maximum load on the $35-\mathrm{mL}$ CPC was transferred as a $1.9 \mathrm{~g}$ load on the $254-\mathrm{mL}$ medium size CPC and $9 \mathrm{~g}$ load on the $812-\mathrm{mL}$ CPC. The maximum productivity of $3.1 \mathrm{mg}$ of carnosol per hour obtained on the small $35-\mathrm{mL}$ rotor was transferred on the $254-\mathrm{mL}$ CPC giving $8.3 \mathrm{mg} / \mathrm{h}$ and, on the larger 812 $\mathrm{mL}$ rotor $49.4 \mathrm{mg}$ of carnosol could be obtained per hour. If the scaling-up in CPC instruments is not directly homothetic, it can be highly predictable through few simple experiments.
\end{abstract}

\section{Keywords}

Centrifugal partition chromatography; countercurrent chromatography; scale-up; rosemary; carnosol; throughput.

\section{INTRODUCTION}

Countercurrent chromatography (CCC) is the preparative purification technique that uses two liquid phases to perform compound separation [13]. The chall1enge of CCC columns is to retain the liquid stationary phase without any solid support. Centrifugal fields are used. Two types of CCC columns reached commercial development: the hydrodynamic CCC columns and the hydrostatic CCC design called Centrifugal Partition Chromatographs (CPC). Both types of CCC columns are available from laboratory scale to industrial scale. They are however based on very different concepts. The hydrodynamic CCC columns are based on coils of open tubes rotating with a planetary motion needing two axes of rotation [1-3]. The technical conception of hydrostatic CCC columns or CPC instruments rely on rotors made of twin-cell chambers that rotate around a single axis. All CCC columns, small or large, hydrostatic or hydrodynamic, can work with the same given biphasic liquid system for a particular separation.

In hydrodynamic $\mathrm{CCC}$ systems, the scale-up was demonstrated to be linear simply considering the ratio of the columns volumes and/or the ratio of the tube sections [4-6]. For hydrostatic CCC instruments, many examples tend to prove that large-scale CPC instruments perform better than small-volume CPCs $[7,8]$. Therefore the exact amount of crude may be significantly higher that predicted by the simple linear value of the column volumes. How can the purification 
capability of a large volume CCC column be fully exploited? Such studies were scarcely reported in the literature $[7,8]$. We recently proposed a protocol called the "free-space between peak method", which we applied on the separation of a maximum amount of selected GUESS compounds. We showed that it is possible, starting with a single analytical injection on a large scale instrument, to predict the exact maximum quantity of sample that can be injected maintaining the desired purification level [9]. This method is used in this work to optimize the purification of carnosol from crude rosemary solvent extracts by CPC.

Rosemary (Rosmarinus officinalis L.) is a well known aromatic and medicinal herb commonly used in the Mediterranean diet. Recent studies have shown the many benefits it could provide for treatment of cancers and heart diseases [10-18]. This pharmacologic activity relies on three main active ingredients: carnosol, carnosic acid and rosmarinic acid. While the two acids are easily isolated via ion-exchange [19], carnosol is quite difficult to isolate from rosemary herb, because of its high instability towards heat, light, solvents [20-24] and its low content in plants. Due to its therapeutic potential, providing carnosol high purity standards has become now of major importance for the pharmaceutical industry, not only to pursue research and toxicological studies, but also to provide a reliable standard for quality control of new drugs.

There is a work using hydrodynamic CCC to isolate carnosol from Rosemary leaves [25]. Injecting $715 \mathrm{mg}$ of methanol extract of rosemary leaves in a $325 \mathrm{~mL}$ hydrodynamic PC Inc CCC instrument with the hexane-ethyl acetatemethanol-water (70/30/14/8 v/v) biphasic system and the upper organic mobile phase at 1.5 $\mathrm{mL} / \mathrm{min}$, Fisher was able to obtain $66 \mathrm{mg}$ of $95 \%$ pure carnosol in 5 hours [25]. There was no attempt to increase the yield or the productivity. No carnosol purification by CPC were found. This paper presents a CPC crnosol separation on a small 25-mL CPC column. It will then illustrate the rapid CPC method development that was performed on rosemary extracts to isolate significant amounts of pure carnosol using a midscale $200-\mathrm{mL}$ rotor and going almost industrial scale with a 1-L rotor. It demonstrates that the methodology developed using standard compounds [9] can be applied to real samples. The method allows for simple and reliable predictable scale-up on hydrostatic CPC instruments.

\section{EXPERIMENTAL SECTION}

\section{Chemicals}

A Rosemary leave extract was purchased from Cooper industries, Melun, France (extract \#1 042 000). According to the manufacturer, the solid extract was made of a $30 \%$ ethanol cold infusion, followed by low-pressure solvent evaporation at $45^{\circ} \mathrm{C}$ to preserve the active compounds. The ratio plant/extract is $5 / 1(\mathrm{w} / \mathrm{w})$. Solvents were supplied by Sigma-Aldrich (Isle d'Abeau, France) and the analytical standards carnosol, carnosic acid and rosemaric acid were obtained from Phytolab (Vestenbergsgreuth, Germany).

\section{Sample preparation}

The analytical standards were prepared in methanol, with carnosol and rosmarinic acid at $250 \mu \mathrm{g} / \mathrm{mL}$ and carnosic acid at $170 \mu \mathrm{g} / \mathrm{mL}$ concentration.

The commercial Rosemary extract was dissolved in the lower phase of the selected biphasic system and sonicated for $10 \mathrm{~min}$. The mixture was then centrifuged at $5000 \mathrm{rpm}$ for 3 min to remove any remaining solid material and the supernatant was collected and directly injected in the CPC instrument.

\section{HPLC Analysis}

The HPLC analysis of rosemary extracts has been adapted from a published method [26]. An Alliance Waters 2690 instrument was used equipped with a $5 \mu \mathrm{m}$ Zorbax SB-Aq 3 x $150 \mathrm{~mm}$ column and a DAD detection system set up at 214 $\mathrm{nm}$. A gradient elution was performed with the solvents A: water with $0.1 \%$ acetic acid and $\mathrm{B}$ : acetonitrile. The gradient program was: $90 \% \mathrm{~A}+$ $10 \%$ B for 0.5 min, next increasing B from $10 \%$ to $24 \%$ in $23 \mathrm{~min}$, and next increasing $\mathrm{B}$ from $24 \%$ to $100 \%$ pure B in $38 \mathrm{~min}$. The flow rate was $0.4 \mathrm{~mL} / \mathrm{min}$ with an injection volume of 20 $\mu \mathrm{L}$. One analysis cycle lasted $62 \mathrm{~min}$. 


\section{Selection of the two-phase solvent system}

Different two-phase solvent systems were tested. The appropriate system was selected based on the partition coefficient, $K$, ratio of the compound concentration in the stationary phase over the concentration in the mobile phase. The $K$ values of the main compounds found in the crude sample should be different enough so that compounds can be separated in a reasonable amount of time. The $K$ values were determined as follows: the selected two-phase solvent system was prepared and let for full equilibration in a separation funnel at room temperature. $2 \mathrm{~mL}$ of upper and lower phases were placed in test tubes and $400 \mathrm{mg}$ of rosemary extract were added in at least two test tubes. Each test tube was shaken for $1 \mathrm{~min}$ and then sonicated for $10 \mathrm{~min}$ for optimal solubilization. The two phases were separated and centrifuged at $5000 \mathrm{rpm}$. The supernatant was collected and dissolved in a 1/10 ratio with the same upper or lower phase, then injected in the HPLC system. A blank analysis of each upper/lower phase was also carried out to check on possible solvent peaks. The $K$ value was calculated as the peak area of the compound in the lower phase divided by the peak area of the compound in the upper phase at the same retention time in the HPLC chromatogram.

\section{Centrifugal Partition Chromatography}

The CPC system was a FCPC A from Kromaton Rousselet Robatel (Annonay, France). This unit can be mounted with different rotors easily interchanged. A $25 \mathrm{~mL}$-rotor was used for method development; a $200 \mathrm{~mL}$ - rotor and a 1 liter-rotor were operated for scale-up studies. The exact volumes of the three rotors mounted in the FCPC A system were experimentally measured as $35 \mathrm{~mL}, 254 \mathrm{~mL}$ and $812 \mathrm{~mL}$, respectively. The FCPC A chamber has a water circulation system that allows for cooling down to $25^{\circ} \mathrm{C}$ using a Julabo cryostat (Colmar, France). An integrated chromatographic device, model Spot Prep II by Armen Instrument (Saint-Avé, France), was equipped with a quaternary pump (1 to $250 \mathrm{~mL} / \mathrm{min}$ ), a stainless steel injection loop $(10$ or $50 \mathrm{~mL})$ and a dual wavelength detection system (set at 210 and $254 \mathrm{~nm}$ ). The Spot Prep II also includes a fraction collector and a data treatment and control unit using the Armen Glider Prep software. The UV signal was also externally treated using the chromatographic AZUR software (Datalys, Grenoble, France).
The liquid stationary phase was the denser and lower aqueous phase of the selected biphasic systems. It was loaded in the selected rotor rotating at $600 \mathrm{rpm}$, with a high flow rate depending on the rotor volume (i.e. $20 \mathrm{~mL} / \mathrm{min}$ to fill the $35-\mathrm{mL}$ rotor in about $3 \mathrm{~min}, 40 \mathrm{~mL} / \mathrm{min}$ to fill the $254-\mathrm{mL}$ rotor in less than $10 \mathrm{~min}$ and 80 $\mathrm{mL} / \mathrm{min}$ filling the $812-\mathrm{mL}$ rotor in $15 \mathrm{~min}$ ). Then the rotation speed was increased so as to reach the desired centrifugal field. The mobile phase, the upper organic phase, was then introduced in the appropriate ascending direction (also called tail-to-head [1-3]), at the desired flow rate. The displaced aqueous stationary phase volume was collected at the column exit until equilibrium was reached as noted by a stabilization of the increasing driving pressure associated with a growing layer of upper mobile phase seen toping the lower phase in the collection vessel. The stationary phase retention was either measured injecting and measuring the retention volume of an un-retained compound (new coccine red) or using the collected volume of displaced lower stationary phase. Injections were performed through the loop, with the sample dissolved either in the mobile (organic upper) phase or in the stationary (aqueous lower) phase. $15 \mathrm{~mL}$ fractions were automatically collected.

The commercial rosemary dry extract was dissolved in the aqueous lower phase of the selected solvent system at a concentration of 500 $\mathrm{mg} / \mathrm{mL}$. The insoluble matter was precipitated at the bottom of a test tube using centrifugation, while the supernatant was directly injected in the 10 or $50 \mathrm{~mL}$ CPC loop.

\section{RESULTS AND DISCUSSION}

\section{CPC method development}

The HPLC analysis of the commercial dry extract revealed that the sample was quite complex with a low carnosol content estimated at $1.6 \mathrm{mg}$ carnosol per gram of rosemary leaves extract $(0.16 \% \mathrm{w} / \mathrm{w})$. The good solvents for carnosol are methanol, ethanol, methyl-ter-butyl ether (MTBE) or dimethyl sulfoxide [27, 28]. Methanol was banned from the tested solvent systems because it was found to enhance the degradation of carnosol into carnosic acid [20, 23, 29]. Therefore it was decided to construct a 
solvent system based on ethanol. A panel of 24 solvent systems were tested using shake-flask method. A solvent system made of heptane/ MTBE/ethanol/water was selected. Both heptane and water are not prone to dissolve carnosol, but they are required to generate the biphasic system. Moreover, water dissolves most of the rosemary unwanted compounds, therefore increasing the selectivity between carnosol and other compounds that partitionned between the two phases.

Different ratios of heptane/MTBE/ethanol/ water were tested. The ascending (or tail-tohead) mode with the upper organic phase was preferred to provide larger carnosol retention in the ethanol-rich lower aqueous stationary phase and recover carnosol in an easy-to-evaporate organic phase. The CPC method development was carried out on the small scale $35-\mathrm{mL}$ rotor in order to gain time, solvents and sample [30].

Increasing the amount of ethanol while keeping the amount of MTBE constant, leads to a better affinity of carnosol and other impurities for the lower phase. As the ratios ethanol/MTBE moved from $2: 1$ to $4: 1$, the carnosol partition coefficient $K$ shifted from 1.5 to 4.4 (Fig. 1A-C). The adjacent impurity was also more retained with its $K$ shifting from 1.2 to 2.6. However, a significant selectivity increase was observed from $\alpha=1.27(1.5 / 1.2)$ to $\alpha=1.69(4.4 / 2.6)$ giving a baseline resolution between the two peaks with the richer ethanol composition 4:1:4:1 v/v. The 3:1:2:1 system could not fractionate all the target constituents of the crude sample (Fig. 1B) whereas the 4:1:4:1 system fractionated four peaks with good resolution, with the carnosol peak being baseline separated from other compounds (Fig. 1C). Therefore, the heptane/ MTBE/ethanol/water 4:1:4:1 v/v system was selected for all further separations.

Fractions between 18 and $27 \mathrm{~min}$ were collected for carnosol analysis as illustrated by Fig. 2B-D. It is clear that Fraction 23 (apex of the CPC carnosol peak in Fig. 1C), is pure carnosol. All impurities have been removed when compared to the crude extract analysis (Fig. 2A) allowing obtaining a pure carnosol peak in less than $30 \mathrm{~min}$ on the small $35-\mathrm{mL}$ rotor. In order to produce significant amounts of carnosol usable as a chemical standard, the sample loading on the small $35-\mathrm{mL}$ column must be maximized, then a scale-up study should be made to transfer the purification to larger instruments so that adequate and optimized carnosol productivity can be reached.

\section{Scale-up methodology}

\section{The free-space between peaks method}

The first step in the scaling-up methodology that we proposed in a recent paper [9] is the quick determination on a small-scale rotor of the freespace available between the compound of interest and its closest impurity. In our case, carnosol partitions in the selected solvent system heptane/MTBE/ethanol/water 4:1:4:1 v/v with a $\mathrm{K}$ coefficient of 4.2. It means that carnosol is mostly $(80 \%)$ located in the aqueous lower phase. So, the lower phase of such system was used to selectively solubilize carnosol from the commercialized dry extract. The commercial rosemary dry extract was dissolved in the 4:1:4:1 lower phase at a concentration of $500 \mathrm{mg} / \mathrm{mL}$. A significant portion of the extract did not dissolve in this phase. The mixture was centrifuged and the solid material was filtered out and discarded. Evaporating the filtrate, it was determined that the maximal amount of crude extract that could be dissolved in the saturated lower phase was 180 $\mathrm{mg} / \mathrm{mL}$ containing $870 \mu \mathrm{g}$ of carnosol or $0.48 \%$ $\mathrm{w} / \mathrm{w}$ of the extracted crude material as determined by HPLC (Fig. 2A). This extraction step enriched the rosemary commercial sample in carnosol by about three times. In all further parts of this work, the extracted and filtrated lower phase solution containing $180 \mathrm{mg} / \mathrm{mL}$ crude rosemary will be used as the mother liquor containing the carnosol to be purified.

Using this sample, an analytical injection was performed on the $35-\mathrm{mL}$ lab-scale rotor injecting $90 \mathrm{mg}(0.5 \mathrm{~mL}$ of the $180 \mathrm{mg} / \mathrm{mL}$ solution). The resulting chromatogram is shown by Fig. 3A. The free-space volume, $\Delta \mathrm{V}$, was calculated as [9]:

$$
\Delta \mathrm{V}=\Delta \mathrm{Vr}-2\left(\sigma_{\mathrm{A}}+\sigma_{\mathrm{B}}\right)
$$

$\Delta \mathrm{Vr}$ is the difference between the retention volumes of the less retained solute $\mathrm{A}$, an unwanted impurity, and the most retained solute $\mathrm{B}$, carnosol, in $\mathrm{mL} ; \Delta \mathrm{V}$ is expressed in $\mathrm{mL}, \sigma$ is the volume standard deviation of each peak. Fig. $3 \mathrm{~A}$ illustrates the determination of a free-space $\Delta \mathrm{V}$ of $18.7 \mathrm{~mL}$ between carnosol and its closest 
impurity for the small-scale CPC of rosemary extract.

The next step of the "free space between peaks" method is to increase the sample injected mass keeping on the same small-scale rotor as much as possible, i.e. up to get touching bands on the compound of interest. Fig. 3B shows the chromatograms obtained increasing the injected volume of $180 \mathrm{mg} / \mathrm{mL}$ aqueous solution of the rosemary extract. Since the $180 \mathrm{mg} / \mathrm{mL}$ solution is the maximum possible concentration for the extract purified, the loading study can only be done increasing the injection volume. A very limited loss of stationary phase was observed since the sample is injected in the stationary phase. Fig. 3B shows the chromatogram evolution during the loading study. Above 1.5 $\mathrm{mL}(270 \mathrm{mg})$ injected, the early eluting impurity peak starts to overlap with the carnosol peak. The maximal column load $\mathrm{V}_{\text {max.inj }}$ is $1.5 \mathrm{~mL}$ in our experimental conditions. This maximum $270 \mathrm{mg}$ load on the small $35-\mathrm{mL}$ rotor contains $1.3 \mathrm{mg}$ of pure carnosol $(0.48 \%)$. The mass per $\Delta \mathrm{V}$ proportionality factor of the method is 14.4 $\mathrm{mg} / \mathrm{mL}$ (270 mg over $18.7 \mathrm{~mL}$ ). The "free space between peaks" method states that the maximum load on a larger CPC column is related by this proportionality factor to the $\Delta \mathrm{V}$ between peaks obtained with an analytical injection done on the larger column with the same liquid system [9].

\section{Scaling-up to semi-preparative 254-ml rotor}

The attempted first transfer was performed on a semi-preparative rotor with a $200-\mathrm{mL}$ column (exact volume $254 \mathrm{~mL}$ ). This type of CPC rotor is nowadays the most widespread rotor in laboratories, as it is usually employed both for method development and small production. The analytical injection volume should not pass $1 \%$ of the column volume. A 2-mL injection volume was selected corresponding to $360 \mathrm{mg}$ of crude rosemary extract. The much higher weight of the 254-mL and its larger number of cells generating more pressure did not allow spinning it at 2200 $\mathrm{rpm}$. The maximum rotor rotation was only 1800 rpm. High flow rates give quick separations but large volumes of stationary phase are flushed out of the column (low Sf killing resolution) [1-3]. Low flow rates allow for high $\mathrm{Sf}$ and good resolution but the experiments are long and the productivity low [31]. Several flow rates were tested between 5 and $50 \mathrm{~mL} / \mathrm{min}$ to select the 20 $\mathrm{mL} / \mathrm{min}$ flow rate as being high enough to give acceptable separation duration and low enough to maintain enough liquid stationary phase. The separation of $2 \mathrm{~mL}(360 \mathrm{mg})$ of crude sample at $20 \mathrm{~mL} / \mathrm{min}$ and $1800 \mathrm{rpm}$ allowed measuring a $\Delta \mathrm{V}$ volume of $131 \mathrm{~mL}$.

The "free space between peaks" method give a $\Delta \mathrm{V}_{1} / \Delta \mathrm{V}_{2}$ ratio of $131 / 18.7=7$ that can be multiplied by the $270 \mathrm{mg}$ maximum load on the $35-\mathrm{mL}$ rotor to predict a $1.9 \mathrm{~g}$ load on the $254-\mathrm{mL}$ rotor. Fig. 4A presents the separation obtained following the method. The carnosol peak is baseline separated from the leading impurity with touching bands as expected. The $1.9 \mathrm{~g}$ injection allows obtaining $9.12 \mathrm{mg}$ of pure carnosol in 50 min (productivity $10.9 \mathrm{mg} / \mathrm{h}$ ) using one liter of upper organic phase.

As previously observed [9], the productivity could be improved at the cost of a slightly lower purity. Increasing the flow rate is interesting since it will produce purified material more quickly. Since there will be stationary phase losses, the resolution will decrease which can be compensated by lowering the mass load. The analytical 35-mL rotor had a maximum productivity at $40 \mathrm{~mL} / \mathrm{min}(2200 \mathrm{rpm})$. Making a 2-mL analytical injection on the 254-mL rotor spinning at $1800 \mathrm{rpm}$ and with a $40 \mathrm{~mL} / \mathrm{min}$ flow rate produced a $\Delta \mathrm{V}$ of $62 \mathrm{~mL}$ only. This tells that it will be possible to inject $62 / 18.7=3.3$ times the maximum mass loaded on the $35-\mathrm{mL}$ rotor that is $0.9 \mathrm{~g}$ or $5 \mathrm{~mL}$ of $180 \mathrm{mg} / \mathrm{mL}$ crude rosemary extract. Fig. 4B shows the baseline separation of the $0.9 \mathrm{~g}$ injected mass done in $20 \mathrm{~min}$. This allowed obtaining $4.32 \mathrm{mg}$ of pure carnosol in 20 min (productivity $13 \mathrm{mg} / \mathrm{h}$ ) using 0.8 liter of organic mobile phase.

\section{Linear scale-up}

Direct linear scale-up was used with hydrodynamic CCC columns [4, 32, 33]. The ratio of the two column volumes is the transfer factor. The optimized separation on a small analytical CCC column is directly transferred on a large scale CCC column by using the same biphasic liquid system and a flow rate increased by the column volume ratio. The injected volume is also multiplied by the column volume ratio. Trying a direct linear scale-up in our case gives a column volume ratio of $7.3(254 \mathrm{~mL} / 35 \mathrm{~mL}=$ 7.3). So the optimized analytical separation with a $5 \mathrm{~mL} / \mathrm{min}$ flow rate and $1.5 \mathrm{ml}(270 \mathrm{mg})$ injected (Fig. 3B) should be linearly transferred onto the $254-\mathrm{mL}$ rotor with a flow rate of 37 
$\mathrm{mL} / \mathrm{min}$ injecting $11 \mathrm{~mL}(2 \mathrm{~g})$ of rosemary extract. Fig. 4C shows the chromatogram obtained in these conditions with a poor separation of carnosol (arrow). It must be noted that the $2200 \mathrm{rpm}$ rotor rotation of the small 35mL column could not be maintained as it should have been; the experimental pressure would pass the maximum permitted pressure on the 254-mL column. As opposite to reported studies [7, 9], in this case, the linear transfer towards the larger column cannot provide identical or better separation, due to pressure limitation on the higher scale rotor. When scaling-up a CPC separation, we strongly suggest users to set first the rotation speed as high as permitted by pressure limitations; then select the best flow rate to achieve the purpose.

\section{Scale up on larger 1-L rotor}

In order to prove that the "free space between peaks" method was applicable to industrial level, the carnosol purification was achieved on a 1-liter rotor (exact volume $812 \mathrm{~mL}$ ). On this kind of rotor, method development and loading studies must be optimized regarding to the amount of solvent and hours spent for that purpose.

Two analytical injections at maximum rotation speeds, $1800 \mathrm{rpm}$, were performed to measure the free-space $\Delta \mathrm{V}$. The first one was performed at $50 \mathrm{~mL} / \mathrm{min}$, which is a relatively low flow rate for the $814-\mathrm{mL}$ rotor since $17 \mathrm{~min}$ are needed for one column volume. However this $50 \mathrm{~mL} / \mathrm{min}$ flow rate should provide the best resolution. The second analytical injection was performed at $100 \mathrm{~mL} / \mathrm{min}$. The free-space $\Delta \mathrm{V}$ obtained at $50 \mathrm{~mL} / \mathrm{min}$ was $623 \mathrm{~mL}$ allowing to calculate the predicted maximum load on the 814 $\mathrm{mL}$ rotor as $623 / 18.7 \times 0.27=9 \mathrm{~g}$. The $\Delta \mathrm{V}$ obtained at $100 \mathrm{~mL} / \mathrm{min}$ was lower, only $436 \mathrm{~mL}$, with a maximum load predicted as $436 / 18.7 \times 0.27$ $=6.3 \mathrm{~g}$ only. However the throughput at 100 $\mathrm{mL} / \mathrm{min}$ should be higher than that at $50 \mathrm{~mL} / \mathrm{min}$.

The predicted quantities of sample were injected at their respective flow rates and the experimental separations are illustrated in Fig. 5. It can be easily observed that baseline resolution of the carnosol peak with touching bands was obtained in both cases. $43 \mathrm{mg}$ of carnosol were obtained in $60 \mathrm{~min}$ in the maximum load configuration (Fig. 5A) giving a productivity of $43 \mathrm{mg} / \mathrm{h}$. In one hour, three liters of mobile phase were used. With the $100 \mathrm{~mL} / \mathrm{min}$ configuration
(Fig. 5B), $30 \mathrm{mg}$ of carnosol were obtained in 30 min that is a productivity of $60 \mathrm{mg} / \mathrm{h}$.

\section{Comparing performances}

The transfer methodology applied on a preparative scale rotor required only two analytical injections to accurately predict the production rates. It is undoubtedly less time- and solvent-consuming than any sample load study on the production scale rotor [31].

During the various scale-up presented, we highlighted the fact that, typical of CPC instruments and not hydrodynamic ones, at maximum rotation speed for a given rotor, a low flow rate provides adequate operating conditions for maximal load, useful for batch production while a higher flow rate may provide a larger throughput, suitable for routine larger production.

Table 1 compiles the various operating conditions and results, in regards with quantities, solvents consumption and experiment duration including the required equilibration times between experiments to be as close as possible to real-world practice. It clearly shows that scale-up in CPC is not linear but can easily be predicted in any operating conditions, using a simple analytical injection. For example, the preparative $812 \mathrm{~mL}$ rotor is 23 times larger than the laboratory $35-\mathrm{mL}$ rotor. In a batch use, it can produce $45 \mathrm{mg}$ per cycle or 32 times more than the $35-\mathrm{mL}$ rotor $(1.4 \mathrm{mg}$ per cycle, Table 1$)$. On a routine process, it exhibits a throughput of almost $50 \mathrm{mg}$ of carnosol purified per hour compared to $3.1 \mathrm{mg}$ per hour for tha small rotor. That is 15.9 times higher. While not linear, scaleup in CPC is definitely and accurately predictable. It is interesting to finish this study noting the small change in carnosol productivity per solvent used: the $35-\mathrm{mL}$ rotor produces $9 \mathrm{mg}$ per liter of organic mobile phase when the 812$\mathrm{mL}$ rotor produces $14.3 \mathrm{mg} / \mathrm{L}$ The intermediate 254-mL rotor had the worst volume productivity of $5.6 \mathrm{mg} / \mathrm{L}$.

\section{CONCLUSION}

The purification of carnosol from Rosmariunus officinalis is an example of predictable scale-up process by CPC. The 
recently proposed method was first investigated on a laboratory scale $35-\mathrm{ml}$ rotor and then predictably scaled-up to a mid-scale 254-mL rotor and further to a preparative scale $812-\mathrm{mL}$ rotor. While linear scale up in CPC is not practical, this study clearly shows that a separation that is rapidly developed at laboratory scale, using minimum amounts of time and solvents, can be transferred at any larger scale in a predictable manner. The "free space between peaks" methodology in elution mode provides a simple way to predict maximum load on any CPC rotor and any operating conditions. While maximum rotation speed is highly recommended, the flow rate needs to be adjusted to the user goal on the production instrument, using few analytical injections. The purification of carnosol at industrial scale level was performed successfully demonstrating the predictive potential of the "free space between peaks" method in scaling-up CPC separation.

\section{Acknowledgments}

K.F. and A.B. thank the French Centre National de la Recherche Scientifique (CNRS, UMR 5280 ISA) for continuous support. E.B. thanks the Kromaton Rousselet-Robatel Company and the French Association Nationale de la Recherche et de la Technologie for a threeyear CIFRE $\mathrm{PhD}$ grant. The authors wish to express their gratitude to $\mathrm{S}$. Bonnet and $\mathrm{C}$. Chertier for their technical help in carnosol quantification and sample stability studies.

\section{REFERENCES}

[1] W.D. Conway, Countercurrent Chromatography, Apparatus, Theory and Applications, VCH Publishers, New York (1990).

[2] A. Berthod, Countercurrent Chromatography: the Support-free liquid stationary phase. Wilson \& Wilson's Comprehensive Analytical Chemistry, Vol. 38, Eslevier, Amsterdam (2002).

[3] Y. Ito, W.D. Conway, High Speed Counercurrent Chromatography, Chemical Analysis, Vol. 198, J. Wiley \& sons, New York (1995).

[4] M. Zhang, S. Ignatova, Q. Liang, F. Wu Jun, I. Sutherland, Y. Wang, G. Luo, Rapid and highthroughput purification of salvianolic acid B from Salvia miltiorrhiza Bunge by highperformance counter-current chromatography, J. Chromatogr. A, 1216 (2009) 3869-3873.
[5] H. Luo, M. Peng, H. Ye, L. Chen, A. Peng, M. Tang, F. Zhang, J. Shi, Predictable and linear scale-up of four phenolic alkaloids separation from the roots of Menispermum dauricum using high-performance counter-current chromatography, J. Chromatogr. B, 878 (2010) 1929-1933.

[6] P. Wood, S. Ignatova, L. Janaway, D. Keay, D. Hawes, I. Garrard, I.A. Sutherland, Countercurrent chromatography separation scaled up from an analytical column to a production column, J. Chromatogr. A, 1151 (2007) 25-30.

[7] I.A. Sutherland, G. Audo, E. Bourton, F. Couillard, D. Fisher, I. Garrard, P. Hewitson, O. Intes, Rapid linear scale-up of a protein separation by centrifugal partition chromatography, J. Chromatogr. A, 1190 (2008) 57-62.

[8] J.-S. Jeon, C.L. Park, A.S. Syed, Y.-M. Kim, I.J. Cho, C.Y. Kim, Preparative separation of sesamin and sesamolin from defatted sesame meal via centrifugal partition chromatography with consecutive sample injection, J. Chromatogr. B, 1011 (2016) 108-113.

[9] E. Bouju, A. Berthod, K. Faure, Scale-up in centrifugal partition chromatography: The "freespace between peaks" method, J. Chromatogr. A, 1409 (2015) 70-78.

[10] S.F. Brennan, M.M. Cantwell, C.R. Cardwell, L.S. Velentzis, J.V. Woodside, Dietary patterns and breast cancer risk: a systematic review and meta-analysis, Am. J. Clin. Nutr., 91 (2010) 1294-1302.

[11] V. Cottet, M. Touvier, A. Fournier, M.S. Touillaud, L. Lafay, F. Clavel-Chapelon, M.-C. Boutron-Ruault, Postmenopausal breast cancer risk and dietary patterns in the E3N-EPIC prospective cohort study, Am. J. Epidemiol., 170 (2009) 1257-1267.

[12] L.B. Dixon, A.F. Subar, U. Peters, J.L. Weissfeld, R.S. Bresalier, A. Risch, A. Schatzkin, R.B. Hayes, Adherence to the USDA Food Guide, DASH Eating Plan, and Mediterranean dietary pattern reduces risk of colorectal adenoma, J. Nutr., 137 (2007) 24432450 .

[13] U. Facchini, M. Camnasio, A. Cantaboni, A. Decarli, C. La Vecchia, Geographical variation of cancer mortality in Italy, Int. J. Epidemiol., 14 (1985) 538-548.

[14] C. Fortes, F. Forastiere, S. Farchi, S. Mallone, T. Trequattrinni, F. Anatra, G. Schmid, C.A. Perucci, The protective effect of the Mediterranean diet on lung cancer, Nutrition and cancer, 46 (2003) 30-37.

[15] S. Piscopo, The Mediterranean diet as a nutrition education, health promotion and disease prevention tool, Pub. Health Nutr., 12 (2009) 1648-1655.

[16] S. Cheung, J. Tai, Anti-proliferative and antioxidant properties of rosemary Rosmarinus officinalis, Oncology Rep., 17 (2007) 1525-1531. 
[17] O. Yesil-Celiktas, C. Sevimli, E. Bedir, F. Vardar-Sukan, Inhibitory effects of rosemary extracts, carnosic acid and rosmarinic acid on the growth of various human cancer cell lines, Plant Foods Hum. Nutr., 65 (2010) 158-163.

[18] L. Almela, B. Sánchez-Muñoz, J.A. FernándezLópez, M.J. Roca, V. Rabe, Liquid chromatograpic-mass spectrometric analysis of phenolics and free radical scavenging activity of rosemary extract from different raw material, $\mathbf{J}$. Chromatogr. A, 1120 (2006) 221-229.

[19] A. Maciuk, A. Toribio, M. Zeches - Hanrot, J.M. Nuzillard, J.H. Renault, M.I. Georgiev, M.P. Ilieva, Purification of rosmarinic acid by strong ion - exchange centrifugal partition chromatography, J. Liq. Chromatogr. Rel. Technol., 28 (2005) 1947-1957.

[20] Y. Zhang, J.P. Smuts, E. Dodbiba, R. Rangarajan, J.C. Lang, D.W. Armstrong, Degradation study of carnosic acid, carnosol, rosmarinic acid, and rosemary extract (Rosmarinus officinalis L.) assessed using HPLC, J. Agric. Food Chem., 60 (2012) 93059314.

[21] N. Mulinacci, M. Innocenti, M. Bellumori, C. Giaccherini, V. Martini, M. Michelozzi, Storage method, drying processes and extraction procedures strongly affect the phenolic fraction of rosemary leaves: an HPLC/DAD/MS study, Talanta, 85 (2011) 167-176.

[22] K. Schwarz, W. Ternes, E. Schmauderer, Antioxidative constituents of Rosmarinus officinalis and Salvia officinalis. III. Stability of phenolic diterpenes of rosemary extracts under thermal stress as required for technological processes, Z. Lebensm.-Unters. Forsch., 195 (1992) 104-107.

[23] X. Liu, J. Du, Y. Ou, H. Xu, X. Chen, A. Zhou, L. He, Y. Cao, Degradation pathway of carnosic acid in methanol solution through isolation and structural identification of its degradation products, Eur. Food Res. Technol., 237 (2013) 617-626.

[24] N. Okamura, Y. Fujimoto, S. Kuwabara, A. Yagi, High-performance liquid chromatographic determination of carnosic acid and carnosol in Rosmarinus officinalis and Salvia officinalis, J. Chromatogr. A, 679 (1994) 381-386.
[25] N. Fischer, B. Weinreich, S. Nitz, F. Drawert, Applications of high-speed counter-current chromatography for the separation and isolation of natural products, J. Chromatogr. A, 538 (1991) 193-202.

[26] J. Tai, S. Cheung, M. Wu, D. Hasman, Antiproliferation effect of Rosemary (Rosmarinus officinalis) on human ovarian cancer cells in vitro, Phytomedicine, 19 (2012) 436-443.

[27] I. Koudous, W. Kunz, J. Strube, Panorama of sustainable solvents for green extraction processes, in: Green Extraction of Natural Products: Theory and Practice, John Wiley \& Sons, 2015, pp. 173-236.

[28] Q. Zhang, E.J.C. van der Klift, H.-G. Janssen, T.A. van Beek, An on-line normal-phase high performance liquid chromatography method for the rapid detection of radical scavengers in nonpolar food matrixes, J. Chromatogr. A, 1216 (2009) 7268-7274.

[29] K. Schwarz, W. Ternes, Antioxidative constituents of Rosmarinus officinalis and Salvia officinalis. II. Isolation of carnosic acid and formation of other phenolic diterpenes, $\mathrm{Z}$. Lebensm Unters. Forch., 195 (1992) 99-103.

[30] K. Faure, N. Mekaoui, J. Meucci, A. Berthod, Solvent selection in $\mathrm{CCC}$ using small volume hydrostatic columns, LC-GC North America, 31 (2013) 132-144.

[31] A.S. Adekenova, P.Y. Sakenova, S.A. Ivasenko, I.A. Khabarov, S.M. Adekenov, A. Berthod, Gram-Scale Purification of Two Sesquiterpene Lactones from Chartolepsis Intermedia Boiss, Chromatographia, 79 (2016) 37-43.

[32] Y. Yuan, B. Wang, L. Chen, H. Luo, D. Fisher, I.A. Sutherland, Y. Wei, How to realize the linear scale-up process for rapid purification using high-performance counter-current chromatography, J. Chromatogr. A, 1194 (2008) 192-198.

[33] I.A. Sutherland, A.S. Graham, G.G. Guillon, D. Hawes, L. Janaway, R. Whiteside, P. Wood, Industrial scale-up of CCC: predictive scale-up, J. Chromatogr. Sci., 39 (2001) 21-28. 
Table 1 Compilation of scale-up conditions and results in the carnosol purification from a rosemary extract.

\begin{tabular}{|c|c|c|c|c|c|c|}
\hline Rotor picture & ats & x 7.3 & & & & fonting \\
\hline Exact volume & \multicolumn{2}{|c|}{$\begin{array}{c}\text { Laboratory scale } \\
\text { 25ml rotor } \\
35 \mathrm{ml}\end{array}$} & \multicolumn{2}{|c|}{$\begin{array}{c}\text { Semi-prep scale } \\
\text { 200ml rotor } \\
254 \mathrm{ml}\end{array}$} & \multicolumn{2}{|c|}{$\begin{array}{c}\text { Preparative scale } \\
\mathbf{1 0 0 0} \mathbf{~ m l} \text { rotor } \\
812 \mathrm{ml}\end{array}$} \\
\hline Objective & $\begin{array}{l}\text { Maximum } \\
\text { load }\end{array}$ & Throughput & $\begin{array}{l}\text { Maximum } \\
\text { load }\end{array}$ & Throughput & $\begin{array}{l}\text { Maximum } \\
\text { load }\end{array}$ & Throughput \\
\hline Criteria & $\Delta V_{\max }$ & $\Delta V / t_{\max }$ & $\Delta V_{\max }$ & $\Delta V / t_{\max }$ & $\Delta V_{\max }$ & $\Delta V / t_{\max }$ \\
\hline $\begin{array}{l}\text { Flow rate } \\
(\mathrm{mL} / \mathrm{min})\end{array}$ & 5 & 10 & 20 & 40 & 50 & 100 \\
\hline $\begin{array}{l}\text { Rotation speed } \\
\text { Centrifugal field }\end{array}$ & \multicolumn{2}{|c|}{$\begin{array}{l}2200 \mathrm{rpm} \\
545 \mathrm{~g}\end{array}$} & \multicolumn{2}{|c|}{$\begin{array}{l}1800 \mathrm{rpm} \\
365 \mathrm{~g}\end{array}$} & \multicolumn{2}{|c|}{$\begin{array}{l}1800 \mathrm{rpm} \\
365 \mathrm{~g}\end{array}$} \\
\hline $\begin{array}{l}\text { Stationary phase } \\
\text { retention, } \mathbf{S f}\end{array}$ & $54 \%$ & $46 \%$ & $66 \%$ & $46 \%$ & $68 \%$ & $49 \%$ \\
\hline Pressure (bars) & 48 & 46 & 54 & 47 & 53 & 54 \\
\hline Injection volume & $1.5 \mathrm{~mL}$ & $1 \mathrm{~mL}$ & $10.5 \mathrm{~mL}$ & $5 \mathrm{~mL}$ & $50 \mathrm{~mL}$ & $35 \mathrm{~mL}$ \\
\hline $\begin{array}{c}\text { Duration of a } \\
\text { cycle }^{*}\end{array}$ & $\begin{array}{l}39 \mathrm{~min} \\
0.65 \mathrm{~h}\end{array}$ & $\begin{array}{l}17 \mathrm{~min} \\
0.28 \mathrm{~h}\end{array}$ & $\begin{array}{l}71 \mathrm{~min} \\
1.18 \mathrm{~h}\end{array}$ & $\begin{array}{c}33 \mathrm{~min} \\
0.55 \mathrm{~h}\end{array}$ & $\begin{array}{l}83 \mathrm{~min} \\
1.38 \mathrm{~h}\end{array}$ & $\begin{array}{l}38 \mathrm{~min} \\
0.63 \mathrm{~h}\end{array}$ \\
\hline $\begin{array}{l}\text { Rosemary extract } \\
\text { injected weight (g) }\end{array}$ & 0.27 & 0.18 & 1.90 & 0.90 & 9.04 & 6.32 \\
\hline $\begin{array}{l}\text { Throughput } \\
\text { crude g/h }\end{array}$ & 0.42 & 0.64 & 1.61 & 1.64 & 6.53 & 10.0 \\
\hline $\begin{array}{l}\text { Throughput } \\
\text { carnosol/cycle }\end{array}$ & $1.4 \mathrm{mg}$ & $0.9 \mathrm{mg}$ & $9.5 \mathrm{mg}$ & $4.5 \mathrm{mg}$ & $45.0 \mathrm{mg}$ & $31.5 \mathrm{mg}$ \\
\hline $\begin{array}{c}\text { Production } \\
\text { carnosol mg/h }\end{array}$ & 2.1 & 3.1 & 7.9 & 8.3 & 32.3 & 49.4 \\
\hline $\begin{array}{l}\text { carnosol per } \\
\text { volume mg/L }\end{array}$ & 10.8 & 9 & 10.3 & 5.6 & 17.6 & 14.3 \\
\hline $\begin{array}{c}\text { Solvent } \\
\text { consumption/cycle }\end{array}$ & $130 \mathrm{~mL}$ & $100 \mathrm{~mL}$ & $0.92 \mathrm{~L}$ & $0.80 \mathrm{~L}$ & $2.55 \mathrm{~L}$ & $2.20 \mathrm{~L}$ \\
\hline $\begin{array}{c}\text { Solvent } \\
\text { consumption/h }\end{array}$ & $190 \mathrm{~mL} / \mathrm{h}$ & $350 \mathrm{~mL} / \mathrm{h}$ & $770 \mathrm{~mL} / \mathrm{h}$ & $1.47 \mathrm{~L} / \mathrm{h}$ & $1.83 \mathrm{~L} / \mathrm{h}$ & $3.45 \mathrm{~L} / \mathrm{h}$ \\
\hline
\end{tabular}

*A full cycle comprises equilibrium (1 column volume), elution and extrusion ( 1 column volume). Flow rate remains the same for all three operations. 

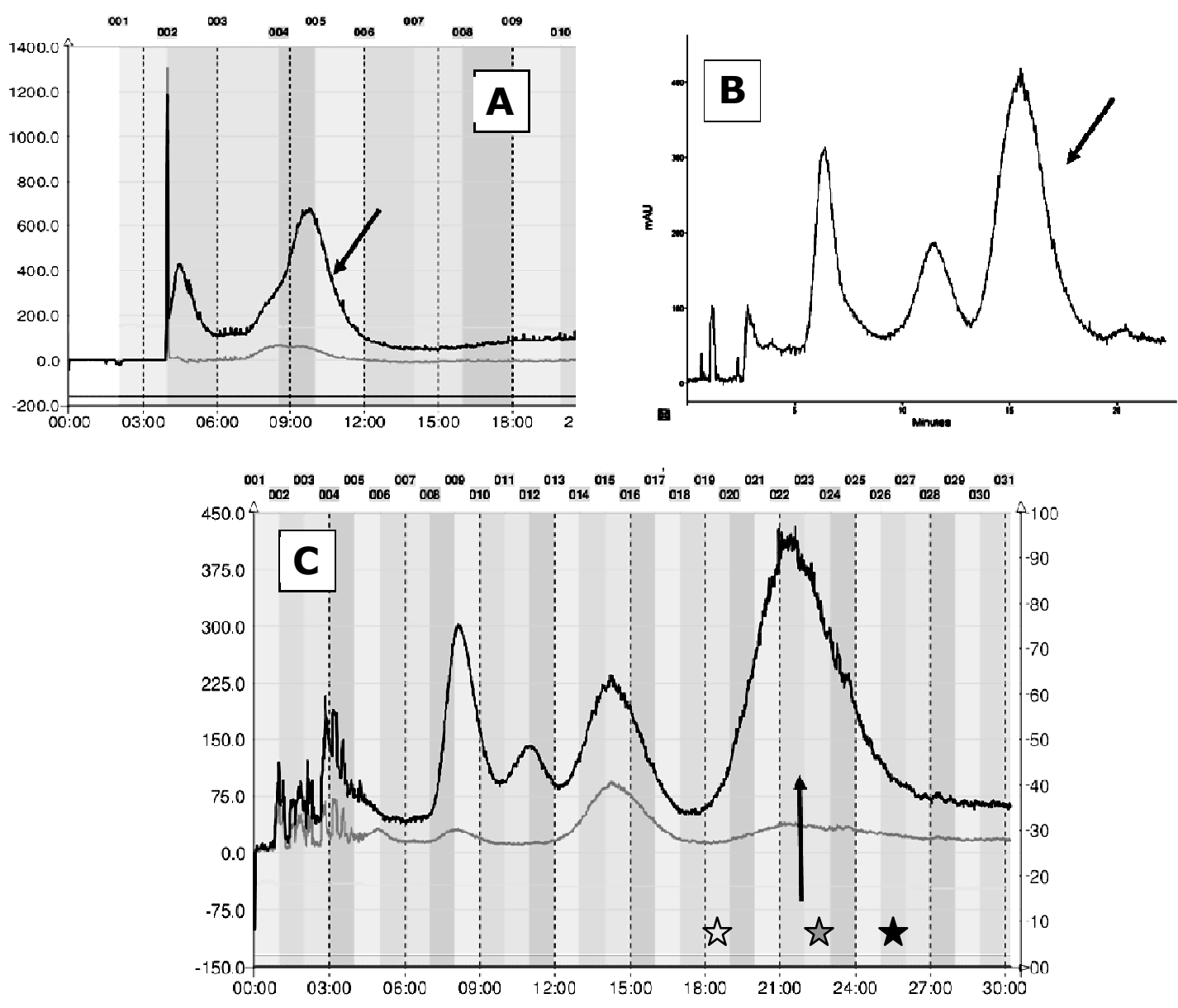

Figure 1. CPC chromatograms of the rosemary extract $(1 \mathrm{~mL} @ 180 \mathrm{mg} / \mathrm{mL})$ obtained with the $35-\mathrm{mL}$ rotor and different liquid system compositions of the heptane/MTBE/ethanol/water system. A-3:1:2:1 $\mathrm{v} / \mathrm{v}(\mathrm{Sf}=63 \%, \mathrm{P}=56$ bar, $\mathrm{K}=1.5), \mathbf{B}-3: 1: 3: 1 \mathrm{v} / \mathrm{v}(\mathrm{Sf}=61 \%, \mathrm{P}=47$ bar, $\mathrm{K}=3.0), \mathbf{C}-4: 1: 4: 1 \mathrm{v} / \mathrm{v}(\mathrm{Sf}$ $=62 \%, \mathrm{P}=46$ bar, $\mathrm{K}=4.4$ ). Rotor rotation: $2200 \mathrm{rpm}$, upper phase mobile phase flow rate: $5 \mathrm{~mL} / \mathrm{min}$ in the ascending direction, detection UV $210 \mathrm{~nm}$. The arrows point at the carnosol peaks. The stars indicate the three fractions analyzed in Figure 2 B, C and D. 

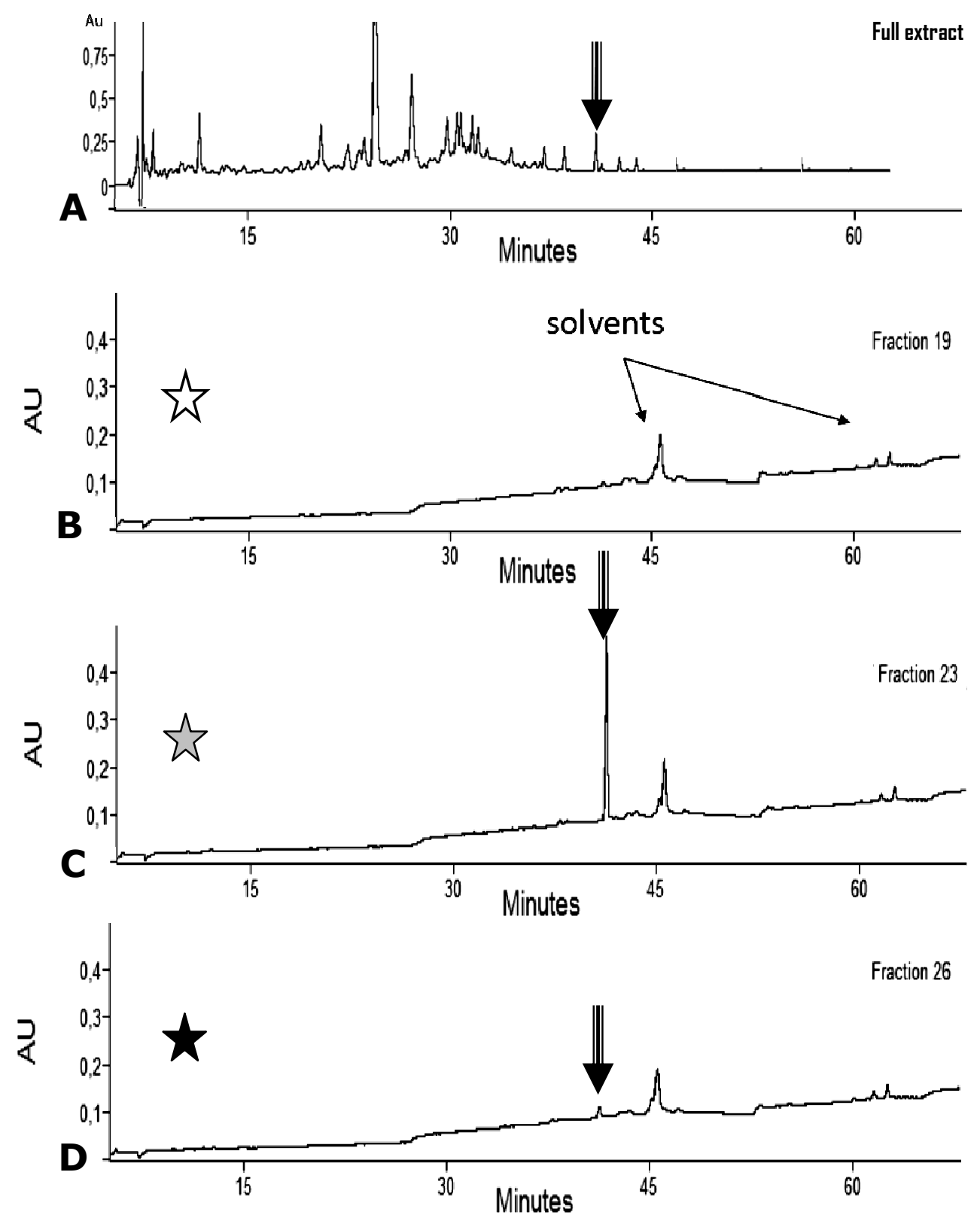

Figure 2. HPLC analyses of A-rosemary extract solubilised in methanol/water 90/10, B-Fraction 19, C-Fraction 23, and D-Fraction 26, in upper phase of the system heptane/MTBE/ethanol/water 4:1:4:1 $\mathrm{v} / \mathrm{v}$ (stars in Figure 1C). Column 5 $\mu \mathrm{m}$ Zorbax SB-Aq 3x150 mm, gradient elution with acetonitrilewater $0.4 \mathrm{~mL} / \mathrm{min}$ flow rate, $20 \mu \mathrm{L}$ injected, UV detection $254 \mathrm{~nm}$. The vertical down-arrows point the carnosol peaks. 

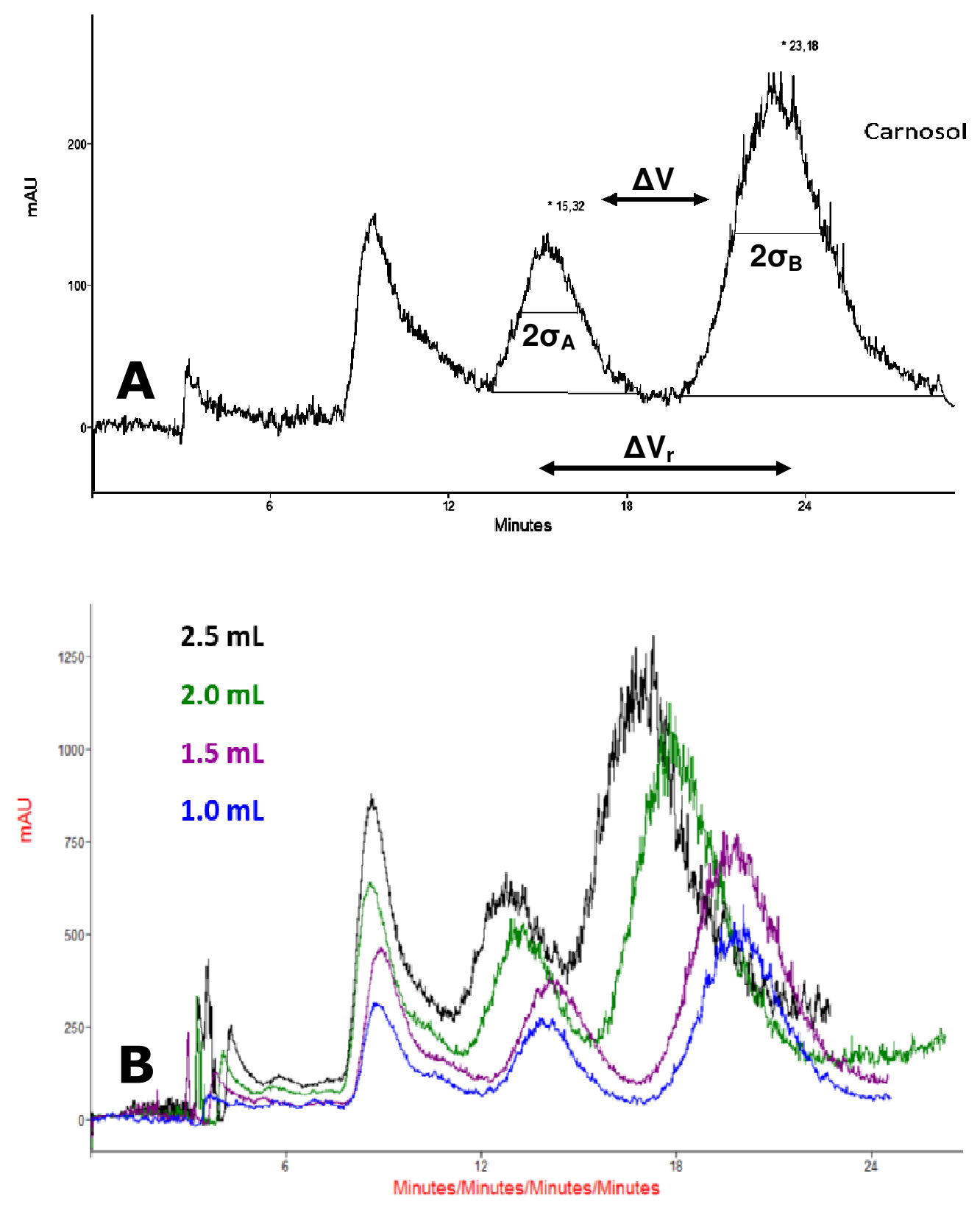

Figure 3. Analytical injections of rosemary extract on a $35 \mathrm{~mL}$-rotor. Solvent system heptane/MTBE/ethanol/water 4:1:4:1 v/v, rotor rotation $2200 \mathrm{rpm}$, organic upper phase flow rate in the ascending mode $=5 \mathrm{~mL} / \mathrm{min},, \mathrm{K}$ carnosol $=4.4$, UV detection $210 \mathrm{~nm}$. A-injection of $90 \mathrm{mg}(0.5$ $\mathrm{mL}$ of $180 \mathrm{mg} / \mathrm{mL}$ solution in the aqueous phase); $\mathrm{Sf}=59 \%, \mathrm{P}=48$ bar; $\mathbf{B}$ - overlay of loading injections $180 \mathrm{mg}(1 \mathrm{~mL}) \mathrm{Sf}=54 \%, 270 \mathrm{mg}(1.5 \mathrm{~mL}) \mathrm{Sf}=54 \%, 360 \mathrm{mg}(2 \mathrm{~mL}) \mathrm{Sf}=50 \%$ and $450 \mathrm{mg}$ $(2.5 \mathrm{~mL}) \mathrm{Sf}=46 \%$. 

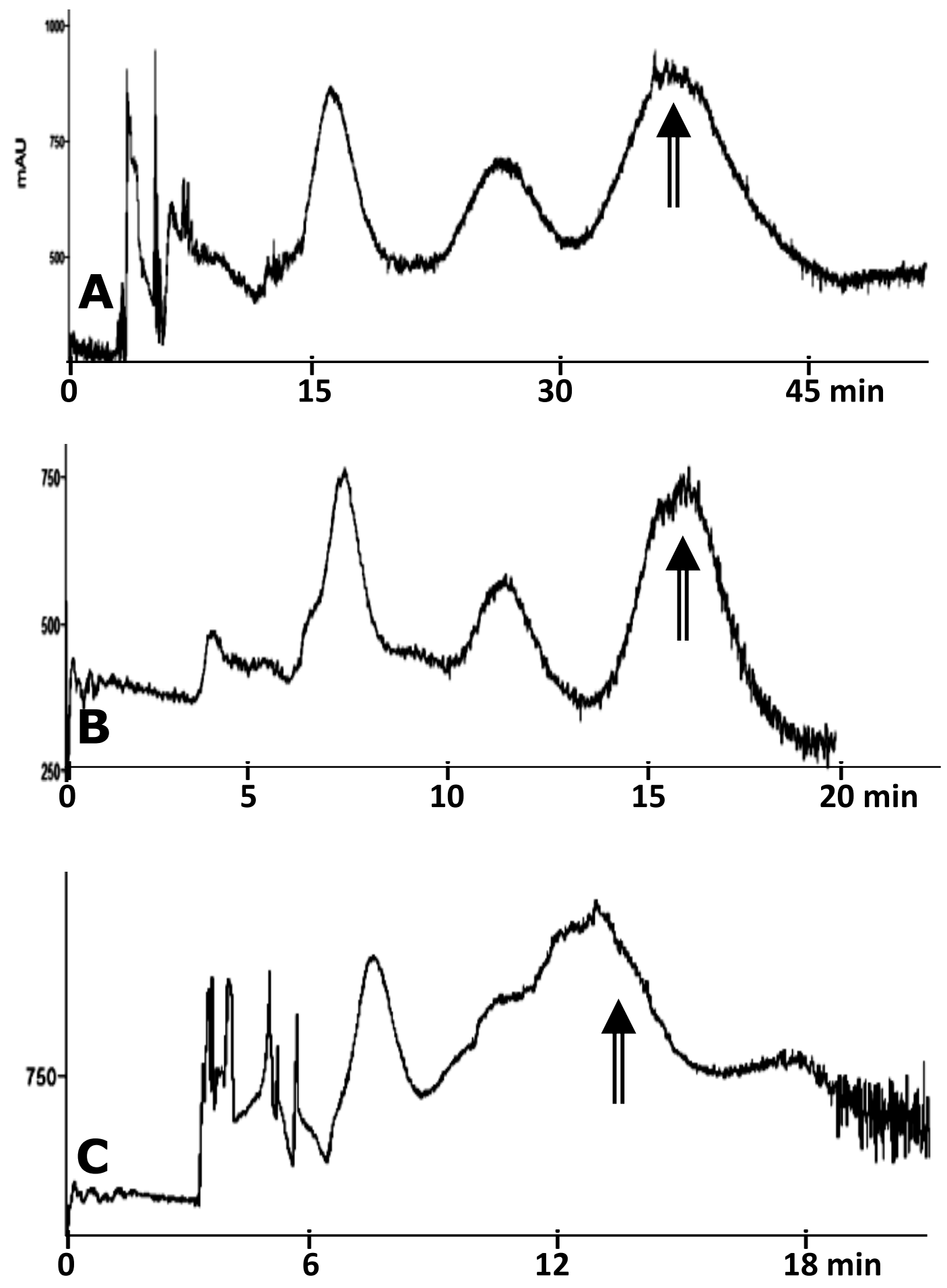

Figure 4. Semi-preparative chromatograms of rosemary extract on a 254-mL CPC column. Solvent system heptane/MTBE/ethanol/water 4:1:4:1 v/v, rotor rotation $1800 \mathrm{rpm}$, organic upper mobile phase in the ascending mode, $\mathrm{K}$ carnosol $=4.4$ (arrows), UV detection $210 \mathrm{~nm}$. A-maximal load, flow rate: $20 \mathrm{~mL} / \mathrm{min}$, injection of $1.9 \mathrm{~g}(10.5 \mathrm{~mL}$ of $180 \mathrm{mg} / \mathrm{mL}$ solution in the aqueous phase); $\mathrm{Sf}=66 \%, \mathrm{P}=$ 54 bar; B-maximum throughput, flow rate: $40 \mathrm{~mL} / \mathrm{min}$, injection of $0.9 \mathrm{~g}(5 \mathrm{~mL}) ; \mathrm{Sf}=46 \%, \mathrm{P}=47$ bar; C- linear scale-up, flow rate: $37 \mathrm{~mL} / \mathrm{min}$, injection of $2 \mathrm{~g}(11 \mathrm{~mL}) \mathrm{Sf}=46 \%, \mathrm{P}=47 \mathrm{bar}$. 

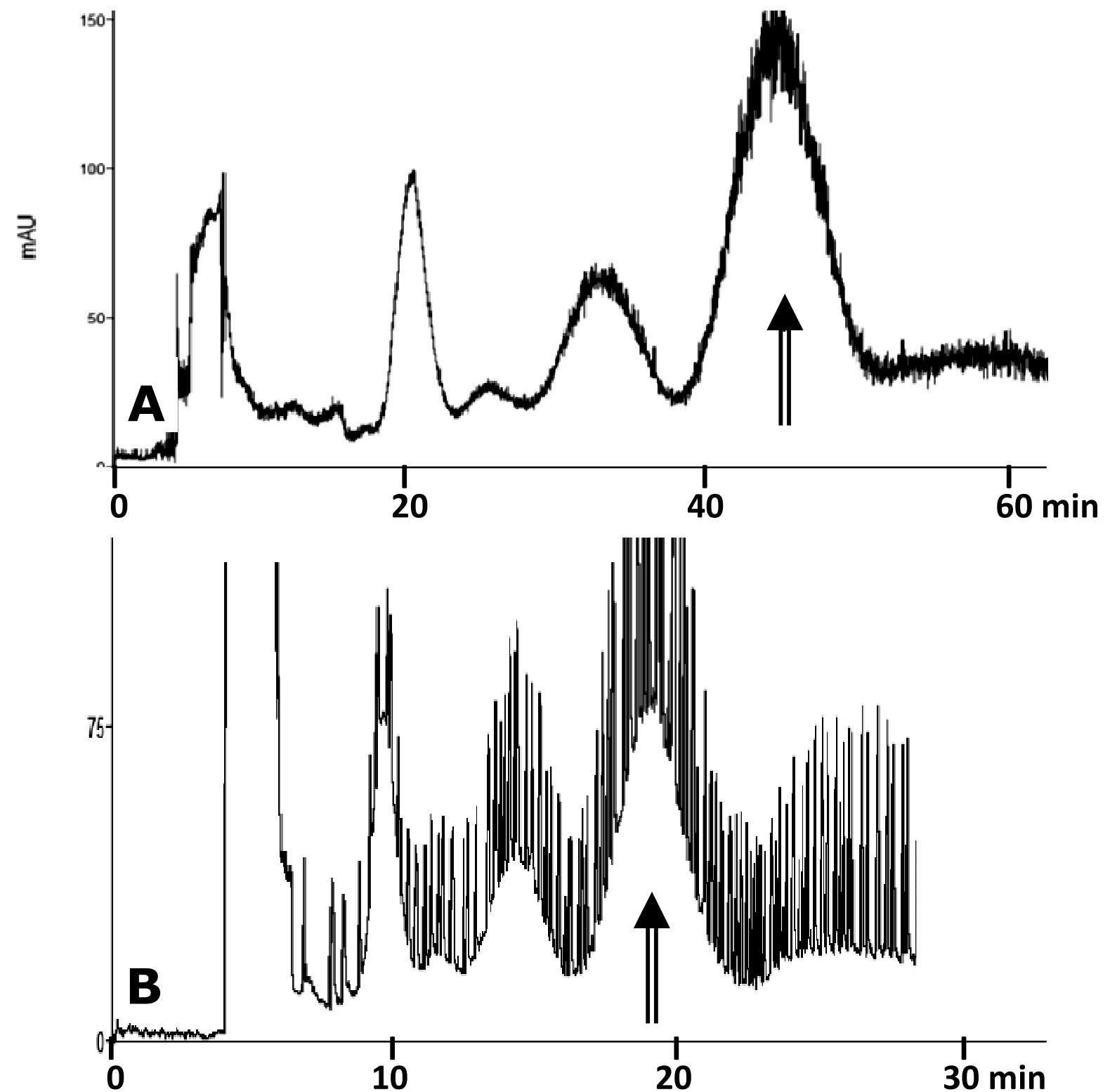

Figure 5 Preparative injections of rosemary extract in a $812-\mathrm{mL}$ rotor. Solvent system heptane/MTBE/ethanol/water 4/1/4/1 v/v, ascending mode. A- Maximal loading performed at 50 $\mathrm{mL} / \mathrm{min}, 1800 \mathrm{rpm} ., \mathrm{V}_{\text {inj }}=50 \mathrm{~mL}(9.0 \mathrm{~g}), \mathrm{Sf}=68 \%, \mathrm{P}=53 \mathrm{bar}$. B- Maximal throughput performed at $100 \mathrm{~mL} / \mathrm{min}, 1800 \mathrm{rpm} ., \mathrm{V}_{\mathrm{inj}}=35 \mathrm{~mL}(6.3 \mathrm{~g}), \mathrm{Sf}=49 \%, \mathrm{P}=54 \mathrm{bar}$. The arrows points at carnosol. 